\title{
FIRST RESPONDER EMERGENCY TRAINING DAN PERILAKU PETUGAS SATUAN PENGAMANAN DALAM PENANGANAN KORBAN KEGAWATDARURATAN
}

\author{
Arif Mulyadi \\ Poltekkes Kemenkes Malang, Prodi Keperawatan Blitar, Jalan Dr. Soetomo No.46 Blitar \\ Email : arif_mulyadi@poltekkes-malang.ac.id
}

\section{The Influence Of First Responder Emergency Training On The Behavior Of Security Officers In The Handling Of Emergency Casualties}

\begin{abstract}
The purpose of this study was to identify the influence of first responder emergency training on behavior which includes knowledge, attitude and skill of security officer in handling emergency casualty. This research is a quantitative research with Pre-Experimental design with One-Group PretestPosttest Design approach. The population is security guard in Blitar City with 30 respondents, with quota sampling technique. To identify the influence, analysis conducted by Paired Sample T-Test with significance level $(p<0,05)$. The results of the analysis show that first responder emergency training can improve knowledge, attitude and skill of security officer in handling emergency casualty.
\end{abstract}

Keywords: behavior, emergency first responder, security officer

\begin{abstract}
Abstrak: Tujuan penelitian ini adalah mengidentifikasi pengaruh first responder emergency training terhadap perilaku yang meliputi pengetahuan, sikap dan keterampilan dari petugas satuan pengamanan dalam penanganan korban kegawatdaruratan. Penelitian ini merupakan penelitian kuantitatif dengan desain Pre-Experimental dengan pendekatan One-Group Pretest-Posttest Design. Populasi adalah petugas Satpam di Kota Blitar dengan sampel sebanyak 30 responden, dengan teknik quota sampling. Untuk mengidentifikasi adanya pengaruh dilakukan analisis dengan uji Paired Sample T-Test dengan tingkat kemaknaan $(p<0,05)$. Hasil analisis menunjukkan bahwa first responder emergency training dapat meningkatkan pengetahuan, sikap dan keterampilan petugas satuan pengamanan dalam penanganan korban kegawatdaruratan.
\end{abstract}

Kata kunci: perilaku, penolong pertama kegawatdaruratan, satpam

\section{PENDAHULUAN}

Peristiwa bencana atau kecelakaan dapat terjadi dalam waktu, tempat dan keadaan yang tak terduga. Pertolongan awal yang cepat dan tepat sangat penting bagi para korban untuk mengantisipasi terjadinya keparahan cedera lebih lanjut. Aekka et al., (2015) menyatakan bahwa faktor utama penyebab kematian dan kecacatan pada kecelakan adalah kurang efektifnya penanganan awal korban saat pra rumah sakit. Sebagian besar kematian akibat trauma terjadi pada masa pre hospital, sebelum korban dibawa ke fasilitas pelayanan kesehatan, baik pada negara berkembang maupun negara yang sudah maju.
Di lingkungan masyarakat saat ini khususnya pada fasilitas umum, gedung perkantoran bahkan perumahan banyak kita temukan petugas satuan pengamanan (Satpam). Satpam adalah satuan kelompok petugas yang dibentuk oleh instansi/ proyek/badan usaha untuk melakukan keamanan fisik (physical security) dalam rangka penyelenggaraan keamanan swakarsa di lingkungan kerjanya. Ketika terjadi suatu bencana atau kecelakaan, Satpam sering menjadi orang pertama yang mendapat laporan atau menemukan korban. Dalam menghadapi situasi tersebut, diperlukan keterampilan khusus bagi para Satpam sebagai emergency first responder, yaitu penolong yang pertama kali tiba ditempat kejadian, yang memiliki 
kemampuan penanganan kasus gawat darurat pada tingkat dasar.

Sebagai emergency first responder petugas Satpam sebagai orang awam khusus harus memiliki kemampuan dalam hal menjaga keselamatan diri, anggota tim, orang sekitar dan korban, menjangkau korban, dapat mengenali dan mengatasi masalah yang mengancam nyawa korban, meminta bantuan, memberikan bantuan hidup dasar, membantu petugas medis dalam pertolongan lanjutan, mencatat data-data korban, berkomunikasi dengan petugas lainnya dan mempersiapkan transportasi untuk korban (Depkes RI, 2006).

Berdasarkan studi pendahuluan yang dilakukan pada bulan Juni 2015 pada 10 orang Satpam di Kota Blitar yang terdiri dari 6 orang Satpam yang bekerja di perkantoran, fasilitas umum dan sekolah serta 4 orang yang bekerja di rumah sakit, diketahui bahwa Satpam yang bekerja di fasilitas umum, perkantoran dan sekolah belum pernah mengikuti pelatihan khusus tentang pertolongan pertama korban pada situasi gawatdarurat, sehingga mereka merasa kebingungan dalam memberikan pertolongan awal ketika menangani seseorang yang sakit atau cedera di lingkungan kerjanya. Sedangkan untuk Satpam yang bekerja di rumah sakit semuanya pernah mengikuti pelatihan kegawatdaruratan karena merupakan program rutin yang dilaksanakan bagi seluruh karyawan rumah sakit.

Pelatihan (training) adalah suatu kegiatan yang bertujuan untuk meningkatkan pengetahuan, keterampilan dan penyesuaian sikap seseorang terhadap tugas-tugas yang ditangani. Menurut Mangkuprawira (2011) memberikan batasan bahwa pelatihan adalah proses mengajarkan pengetahuan dan keahlian serta sikap agar seseorang semakin terampil dan mampu melaksanakan tanggungjawabnya sesuai standar. Pelatihan merujuk pada keterampilan bekerja (vocational) yang dapat digunakan segera.
Pelatihan mengembangkan tiga unsur perilaku yang berfungsi untuk pemberdayaan individu maupun kelompok dalam misi tertentu yang terdiri dari: 1) pengetahuan, menyangkut pengetahuanpengetahuan praktis yang bersifat umum dan harus dimiliki setiap individu dalam organisasi, 2) keterampilan, menitikberatkan pada aplikasi lapangan agar output yang dihasilkan sesuai standar kebutuhan, dan 3) sikap, menyangkut cara pandang, pola pikir atau konsep diri yang teraktualisasi melalui perilaku (action). Prinsip dari pelatihan adalah proses pembentukan individu mulai dari belum tahu menjadi tahu, sesudah tahu menjadi terampil dan sesudah terampil manjadi bertanggungjawab.

Berdasarkan latar belakang di atas maka peneliti terdorong untuk melakukan penelitian tentang pengaruh first responder emergency training terhadap perilaku petugas satuan pengamanan dalam penanganan korban kegawatdaruratan di Kota Blitar. Tujuan dari penelitian ini adalah untuk mengetahui pengaruh first responder emergency training terhadap perilaku yang meliputi pengetahuan, sikap dan keterampilan petugas satuan pengamanan dalam penanganan korban kegawatdaruratan.

\section{METODE PENELITIAN}

Penelitian inimerupakan penelitian kuantitatif dengan desain Pre-Experimental dengan pendekatan One-Group Pretest-Posttest Design, dimana hubungan sebab akibat diungkapkan dengan eksperimen yaitu peneliti memberikan perlakuan dan observasi dilakukan sebanyak dua kali pada sebelum dan sesudah eksperimen. Subjek penelitian dilakukan secara non random dan tidak menggunakan variabel kontrol.

Populasi dalam penelitian ini adalah petugas Satuan Pengamanan (Satpam) di Kota Blitar yang terdaftar pada Satuan Bimas Polres Blitar Kota sebanyak 305 orang. Sedangkan sampel dalam penelitian ini adalah petugas Satpam 
sejumlah 30 orang yang terdiri dari Satpam yang bekerja di fasilitas umum (gedung perkantoran, bank, sekolah dll) dengan teknik pengambilan sampel quota sampling.

Pengumpulan data dilakukan dengan terlebih dahulu melakukan pengukuran pengetahuan, sikap dan ketrampilan responden dalam penanganan korban gawatdarurat sebelum diberikan pelatihan. Kemudian melakukan First Responder Emergency Training kepada seluruh responden dengan 2 orang trainer yang telah memiliki sertifikat TOT dan dibantu oleh fasilitator memiliki sertifikat BTCLS. Selanjutnya melakukan pengukuran kembali pengetahuan, sikap dan ketrampilan responden dalam penanganan korban gawatdarurat setelah diberikan pelatihan.

Data yang telah didapatkan selanjutnya dianalisis dengan teknik analisis data secara deskriptif dan parametrik. Penggunaan teknik analisis data secara deskriptif untuk memperoleh gambaran karakteristik penyebaran nilai setiap variabel yang diteliti. Analisis deskriptif digunakan dalam hal penyajian data pada analisis univariat. Penyajian data dengan menggunakan distribusi frekuensi. Sedangkan untuk menguji hipotesis digunakan uji Paired Sample T-Test menggunakan program SPSS 17.0 dengan tingkat kemaknaan $(\mathrm{p}<0,05)$. Sebelum dilakukan pengujian hipotesis, terlebih dahulu dilakukan uji asumsi normalitas dengan menggunakan uji Saphiro-Wilk $(\mathrm{n} \leq 50)$. Berdasarkan hasil Test of Normality Shapiro-Wilk diperoleh hasil nilai kemaknan untuk seluruh kelompok data (pengetahuan, sikap, keterampilan sebelum dan setelah pelatihan) adalah $>0,05$ (hasil uji terlampir). Dengan demikian dapat diambil kesimpulan bahwa distribusi data adalah normal sehingga memenuhi syarat untuk melakukan uji hipotesis menggunakan uji t berpasangan.

\section{HASIL PENELITIAN}

Beberapa karakteristik petugas Satpam yang mengikuti First Responder Emergency Training dapat dilihat pada tabel 1. Tabel 1 menggambarkan beberapa karakteristik responden yaitu petugas Satpam yang berjumlah total 30 orang. Berdasarkan tabel tersebut tampak bahwa sebagian besar petugas keamanan (Satpam) berada pada usia produktif (20-40 tahun), tingkat pendidikan menengah (SMA sebanyak 96,7\%), telah memiliki pengalaman bekerja 1-10 tahun (90\%) dan bekerja di fasilitasfasilitas umum yang berhubungan dengan pelayanan masyarakat. Hal tersebut menunjukkan para Satpam cukup memiliki kemampuan dan memungkinkan untuk dilatih khususnya sebagai emergency first responder (penolong pertama kedaruratan).

Hasil penelitian menunjukkan responden (Satpam) hampir seluruhnya yaitu 27 orang $(90 \%)$ belum pernah mendapatkan pelatihan yang berkaitan dengan pertolongan pertama pada korban kecelakaan (P3K), dan hanya 3 orang yang pernah mengikuti pelatihan $\mathrm{P} 3 \mathrm{~K}$ yaitu 2 orang $(6,7 \%)$ lebih dari 1 kali serta 1 orang $(3,3 \%)$ pernah hanya 1 kali.

Berdasarkan pengalaman menolong, lebih dari setengahnya (60\%) sudah pernah melaku-

Tabel 1. Karakteristik Responden

\begin{tabular}{lcc}
\hline Karakteristik & f & $\%$ \\
\hline Umur (tahun) & & \\
$-20-30$ & 14 & 46,7 \\
$-31-40$ & 11 & 36,7 \\
- $41-50$ & 5 & 16,7 \\
Tingkat Pendidikan & & \\
- SMP & 1 & 3,3 \\
- SMA & 29 & 96,7 \\
Lama menjadi Satpam & & \\
- 1-10 tahun & 27 & 90 \\
- >10 tahun & 3 & 10 \\
Tempat kerja sekarang & & \\
- Sekolah/Kampus & 9 & 30 \\
- Instansi pemerintah & 4 & 13,3 \\
- Bank & 7 & 23,3 \\
- Perusahaan Swasta & 10 & 33,3 \\
\hline
\end{tabular}


kan tindakan pertolongan terhadap korban kedaruratan di lingkungan kerjanya. Hal tersebut dapat menunjukkan bahwa Satpam sangat berpotensi menjadi penolong pertama bagi korban kedaruratan sehari-hari.

Hasil penelitian diketahui, hampir seluruh responden tidak memilikiatau menyimpan nomor panggilan darurat rumah sakit atau UGD pada telepon seluler pribadi. Hal tersebut dapat menunjukkan bahwa Satpam masih kurang siap dalam melakukan prosedur pertolongan pertama yang sesuai standar pada korban kecelakaan sehari-hari.

Dalam hal pertolongan pertama pada korban tidak sadar, tindakan yang paling banyak dilakukan Satpam adalah membawa korban ke tempat aman $(50 \%)$, namun masih banyak pula yang memberikan bau-bauan merangsang (26,7\%) sebagaimana pada Gambar 1.

Gambar 2 berikut menunjukkan perubahan tingkat pengetahuan, sikap dan tindakan Satpam pada sebelum dan setelah mendapatkan pelatihan First Responder Emergency Training berdasarkan rerata skor pada pre test dan posttest. Berdasarkan diagram tersebut secara keseluruhan tampak bahwa terjadi peningkatan pengetahuan, sikap dan tindakan Satpam setelah mendapatkan pelatihan.

Apabila dilihat berdasarkan skor rerata (Gambar 2) pada setiap variabel dan dikaitkan dengan kategori menurut Nursalam (2008) maka dapat dikatakan bahwa untuk pengetahuan sebelum pelatihan rerata skornya adalah 42,4 termasuk kategori Kurang $(<56)$ namun meningkat menjadi 70,4 atau kategori Cukup (56-75). Sedangkan untuk variabel sikap sebelum pelatihan rerata skornya 66,7 termasuk kategori Cukup, dan meningkat menjadi kategori Baik setelah pelatihan yaitu skor 77,7 (> 75). Perubahan yang lebih signifikan tampak pada variabel keterampilan dimana terjadi peningkatan dari kategori Kurang dengan rerata skor 41,9 menjadi kategori Baik setelah diberikan pelatihan yaitu skor 78,7 (kategori Baik > 75).

Uji hipotesis dilakukan dengan uji $\mathrm{t}$ berpasangan (Paired Sample T-Test) didapatkan nilai Signifikansi (Sig. (2 tailed)) 0,000 atau $\mathrm{p}<0,05$, maka dapat dikatakan bahwa terdapat perbedaan rerata yang bermakna pada pengetahuan, sikap dan tindakan sebelum dan setelah dilakukan pelatihan First Responder Emergency Training pada petugas keamanan

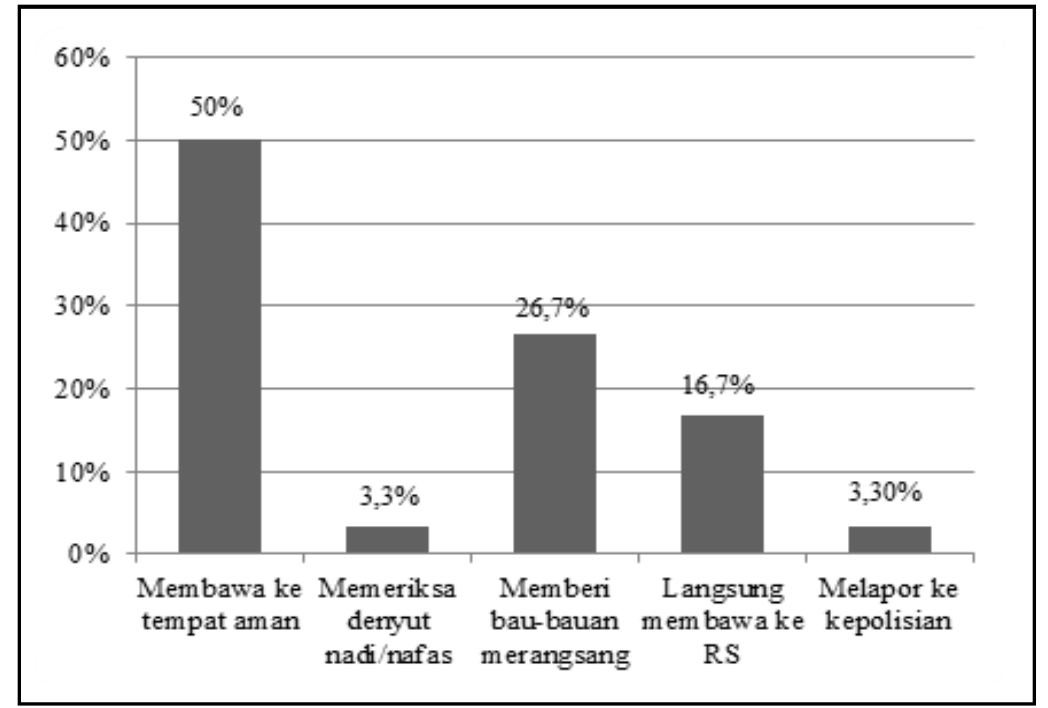

Gambar 1. Tindakan awal saat menolong korban tidak sadar $(\mathrm{n}=30)$ 


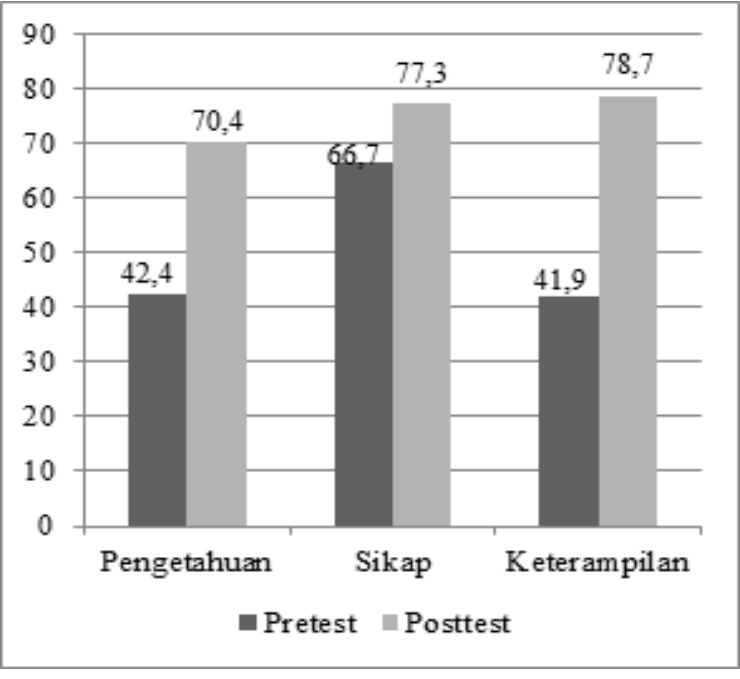

Gambar 2. Perbedaan perilaku Satpam dalam penanganan korban kedaruratan sebelum dan setelah mendapat pelatihan First Responder Emergency Training $(\mathbf{n}=30)$

(Satpam), atau dengan kata lain terdapat pengaruh yang bermakna First Responder Emergency Training terhadap pengetahuan, sikap dan tindakan petugas keamanan dalam penanganan korban kedaruratan.

\section{PEMBAHASAN}

Berdasarkan hasil penelitian menunjukkan bahwa sebagian besar petugas keamanan (Satpam) berada pada usia produktif (20-40 tahun), tingkat pendidikan menengah (SMA sebanyak 96,7\%), telah memiliki pengalaman bekerja 1-10 tahun (90\%) dan bekerja di fasilitas-fasilitas umumyang berhubungan dengan pelayanan masyarakat. Hal tersebut menunjukkan para Satpam cukup memiliki kemampuan dan memungkinkan untuk dilatih khususnya sebagai emergency first responder (penolong pertama kedaruratan). Berkaitan dengan usia seseorang atau anggota suatu organisasi Gatot dan Adisasmito (2005) mengemukakan bahwa. usia menentukan seseorang untuk bekerja, termasuk juga dalam merespon stimulus yang diberikan dari pihak lain. Karyawan dengan usia lebih tua akan semakin mampu menunjukkan kematangan jiwa, bijaksana, berfikir rasional, mengendalikan emosi, toleran terhadap pandangan dan perilaku yang berbeda darinya serta semakin dapat menunjukkan kematangan intelektual dan psikologisnya. Oleh karena itu, semakin tua usia seseorang seharusnya akan semakin terampil dan peka dalam melaksanakan pekerjaannya, karena salah satu kelebihan manusia dari makhluk lainnya adalah kemampuan belajar dari pengalaman.

Tingkat pendidikan juga dapat mempengaruhi perilaku seseorang. Tingkat pendidikan seseorang berpengaruh dalam memberikan respon terhadap sesuatu yang datang dari luar. Orang berpendidikan tinggi akan lebih rasional dan kreatif serta terbuka dalam menerima adanya bermacam usaha pembaharuan. Ia juga akan lebih dapat menyesuaikan diri terhadap berbagai perubahan. Pendidikan yang dicapai seseorang diharapkan menjadi faktor determinan produktifitas antara lain knowledge, skills, abilities, attitude dan behavior yang cukup dalam menjalankan aktifitas pekerjaannya (Azwar, 2011). Dalam hal masa kerja, belum ada bukti yang menunjukkan bahwa semakin lama orang bekerja maka tingkat produktifitasnya meningkat. Namun demikian banyak penelitian yang menyimpulkan bahwa semakin lama seorang karyawan bekerja, semakin rendah keinginan karyawan untuk meninggalkan pekerjaannya. Dengan makin lama masa kerja maka makin terampil dalam melaksanakan pekerjaan (Gatot \& Adisasmito, 2005). Masa kerja yang lama cenderung akan membuat seorang pegawai lebih merasa betah dalam suatu organisasi, hal ini dapat disebabkan diantaranya karena telah beradaptasi dengan lingkungannya yang cukup lama sehingga seorang pegawai akan merasa nyaman dengan pekerjaannya.

Hasil penelitian juga menunjukkan bahwa responden (Satpam) hampir seluruhnya yaitu 27 
orang $(90 \%)$ belum pernah mendapatkan pelatihan yang berkaitan dengan pertolongan pertama pada korban kecelakaan (P3K), dan hanya 3 orang yang pernah mengikuti pelatihan P3K yaitu 2 orang $(6,7 \%)$ lebih dari 1 kali serta 1 orang $(3,3 \%)$ pernah hanya 1 kali. Sedangkan hasil data lainnya menunjukkan bahwa responden (Satpam) lebih dari setengahnya (60\%) sudah pernah melakukan pertolongan terhadap korban kedaruratan di lingkungan kerjanya. Hal tersebut dapat menunjukkan bahwa Satpam sangat berpotensi menjadi penolong pertama bagi korban kedaruratan sehari-hari. Fakta tersebut menunjukkan betapa pentingnya peningkatan pengetahuan dan kemampuan petugas keamanan dalam penanganan kondisi dan korban kegawatdaruratan sehari-hari mengingat makin meningkatnya risiko kejadian bencana dan kecelakaan di masyarakat. Aekka et al., (2015) mengemukakan bahwa banyak kematian akibat kasus trauma terjadi pada fase pre hospital sebelum korban mendapat penanganan di rumah sakit. Penanganan awal yang cepat dan transportasi yang tepat dapat menigkatkan tingkat keberhasilan penanganan korban dengan cara mengurangi risiko kematian dan insiden kecacatan pada korban.

Fakta lainnya yang didapatkan dalam penelitian ini yaitu bahwa Satpam hampir seluruhnya tidak memilikiatau menyimpan nomor panggilan darurat rumah sakit atau UGD pada telepon seluler pribadi. Hal tersebut dapat menunjukkan bahwa Satpam masih kurang siap dalam melakukan prosedur pertolongan pertama yang sesuai standar pada korban kecelakaan sehari-hari. Standar prosedur operasional dalam melakukan pertolongan pertama mengharuskan penolong menghubungi atau meminta orang lain untuk menghubungi timambulance/UGD. Namun apabila penolong tidak mengetahui nomor ambulance maka dapat terjadi penundaan waktu dalam penanganan korban.
Hasil jawaban kuesioner pada saat pretest tentang apa yang dilakukan responden ketika menemukan korban yang tidak sadar menunjukkan bahwa hal yang paling banyak dilakukan Satpam adalah membawa korban ke tempat aman $(50 \%)$, namun masih banyak pula yang memberikan bau-bauan merangsang (26,7\%). Kondisi tidak sadar dapat disebabkan oleh barbagai hal diantaranya akibat serangan jantung, stroke atau syncope (pingsan). Ketidaktahuan penolong tentang ciri-ciri dan penyebab korban tidak sadar dapat berisiko kesalahan dalam memberikan pertolongan sehingga dapat berakibat fatal bagi korban.

Hasil pengukuran terhadap variabel pengetahuan, sikap dan tindakan menunjukkan bahwa tingkat pengetahuan Satpam tentang pertolongan pertama dalam kedaruratan masih Kurang, namun terjadi peningkatan setelah diberikan pelatihan menjadi kategori Cukup. Sedangkan untuk variabel sikap sebelum pelatihan termasuk kategori Cukup, dan meningkat menjadi kategori Baik setelah pelatihan. Hal itu dapat terjadi karena karakteristik petugas Satpam yang mengikuti pelatihan berdasarkan tingkat pendidikan pada umumnya berada pada tingkat menengah (SMP/ SMA), sehingga masih memiliki keterbatasan dalam menginternalisasi dan menganalisis konsep/ teoriuntuk kemudian menjawab pertanyaan atau pernyataan yang diberikan dalam kuesioner.

Perubahan yang lebih signifikan tampak pada variabel ketrampilan dimana terjadi peningkatan dari kategori Kurang menjadi kategori Baik setelah diberikan pelatihan. Hasil tersebut dapat terjadi karena pemberian keterampilan kepada peserta dilakukan dengan metode praktik dalam skill session dimana metode tersebut lebih dapat diterima oleh peserta karena dapat melihat dan melakukan berbagai keterampilan yang diajarkan secara langsung berdasarkan contoh atau panduan yang diberikan oleh pelatih/instruktur. 
Menurut Notoatmojo (2010) keterampilan (skill) merupakan bagian dari ranah psikomotor yang membentuk perilaku manusia dan kualitas keterampilan tersebut dapat berupa praktik terpimpin (guided response) dimana seseorang melakukan sesuatu berdasarkan tuntunan atau menggunakan panduan.

Hasil penelitian menunjukkan bahwa terdapat perbedaan rerata yang bermakna pada pengetahuan, sikap dan tindakan sebelum dan setelah dilakukan pelatihan First Responder Emergency Training pada petugas keamanan (Satpam), atau dengan kata lain terdapat pengaruh yang bermakna First Responder Emergency Training terhadap pengetahuan, sikap dan tindakan petugas keamanan dalam penanganan korban kedaruratan. Hal tersebut menunjukkan bahwa metode pelatihan tersebut efektif dalam meningkatkan kemampuan kalangan non medis atau orang awam dalam memahami konsep dan penanganan korban khususnya pada fase pre hospital. Peserta menunjukkan peningkatan kompetensi khususnya dalam penanganan korban tersedak, penanganan syncope, melakukan bantuan hidup dasar dan melakukan stabilisasi, evakuasi/transportasi korban.

Modifikasi metode dapat dilakukan di masa yang akan datang misalnya dengan meningkatkan rasio pelatih dengan peserta menjadi 1:2 atau dengan menambah durasi waktu pada skill session, sehingga keberhasilan dan efektifitas pelatihan kegawatdaruratan bagi orang awam dapat lebih baik.

\section{PENUTUP}

Hasil penelitian ini menunjukkan bahwa pemberian pelatihan First Responder Emergency Training dapat meningkatkan perilaku petugas keamanan yang meliputi pengetahuan, sikap dan terutama pada tindakan atau keterampilan petugas keamanan (Satpam) dalam penanganan korban kedaruratan. Hal tersebut menunjukkan bahwa metode pelatihan tersebut efektif dalam meningkatkan kemampuan kalangan non medis atau orang awam dalam memahami konsep dan melakukan penanganan korban kedaruratan.

Diperlukan upaya dari semua pihak dan stakeholder untuk dapat meningkatkan kapasitas masyarakat awam dalam melakukan pertolongan pertama kegawatdaruratan melalui sosialisasi dan pengembangan metode pelatihan yang lebih efektif dan efisien di masa yang akan datang.

\section{DAFTAR PUSTAKA}

Aekka A, Abraham R, Hollis M, et al. (2015). Prehospital trauma care education for first responders in India. Journal of surgical research 197 (2015) 331-338

Arikunto, S. (2006). Prosedur Penelitian: Suatu Pendekatan Praktek. Jakarta: Rhineka Cipta.

Azwar, S. (2011). Sikap Manusia. Yogyakarta: Pustaka Pelajar

Depkes RI. (2006). Kurikulum Pelatihan Penolong Pertama Kedaruratan (First Responder Emergency Training). Dirjen Bina Kesehatan Masyarakat Depkes RI. Jakarta.

Gatot, D.B., \& Adisasmito, W., (2005). Hubungan karakteristik perawat, isi pekerjaan dan lingkungan terhadap kepuasan kerja perawat di instalasi rawat inap RSUD Gunung Djati Cirebon. Makara Kesehatan 9(1), 1-8

Mangkuprawira, S. (2011). Manajemen Sumber Daya Manusia Strategik (Edisi 2). Jakarta: Ghalia Indonesia

Notoatmodjo. (2010). Ilmu Perilaku Kesehatan. Jakarta : Rineka Cipta.

Nursalam, (2008). Konsep dan Penerapan Metodologi Penelitian Ilmu Keperawatan. Jakarta : Salemba Medika. 
Riyanto, A. (2011). Aplikasi Metodologi Penelitian Kesehatan. Yogyakarta: Nuha Medika. Hal : 57-60

Siswanto, S. (2013). Metodologi Penelitian Kesehatan dan Kedokteran. Yogyakarta: Bursa Ilmu. Hal: 47-52

Wood, G.L., \& Haber, J. (2006). Nursing research methods and critical appraisal for evidence-based practice. St. Louis, Missouri: Mosby Elsevier 